\title{
Effect of supplemental $\beta$-carotene in the periparturient diet on plasma vitamin A and $\beta$-carotene concentrations and lymphocyte proliferation in Holstein cows
}

\author{
W.J. He' ${ }^{1}$ Q.D. Zhang ${ }^{2}$, L.P. Ren $^{1}$ and Q.X. Meng ${ }^{1,3}$ \\ ${ }^{1}$ State Key Laboratory of Animal Nutrition, Beef Cattle Research Center and College of Animal \\ Science and Technology, China Agricultural University \\ Beijing 100094, P.R. China \\ ${ }^{2}$ Chinese Academy of Agricultural Engineering \\ Beijing 100026, P.R. China
}

\begin{abstract}
Thirty six lactating Holstein cows were selected based on identical parity, milk yield, body weight and body condition score to study the effect of supplemental $\beta$-carotene in the periparturient diet on plasma vitamin A (VA) and $\beta$-carotene concentrations and lymphocyte proliferation. The cows were randomly allotted into three groups and individually fed with one of three treatment diets: 1. control diet (basic diet $+150,000 \mathrm{IU} \mathrm{VA} / \mathrm{cow} /$ day), 2 . control diet $+300 \mathrm{mg} \beta$-carotene/ cow/day, and 3. control diet $+600 \mathrm{mg} \beta$-carotene/cow/day. The results showed that supplemental $\beta$-carotene increased the concentration of VA and $\beta$-carotene in plasma, and increased the lymphocyte proliferation with adequate VA in the diet during periparturient period $(\mathrm{P}<0.01)$.
\end{abstract}

KEY WORDS: $\beta$-carotene, plasma, lymphocyte proliferation, cows

\section{INTRODUCTION}

In the past, it was thought that the role of $\beta$-carotene was only an origin of vitamin $\mathrm{A}$ (VA), so there was no need to supply additional $\beta$-carotene if adequate VA included in the diet. A new research, however, showed that $\beta$-carotene enhances the specific and non-specific immunity, promotes the proliferative response of mitogenstimulated lymphocytes and increases the number of specific lymphocyte subsets,

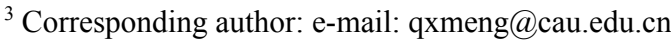


stimulates the generation of multiple cytokines (Boon, 1993). It is still unclear whether $\beta$-carotene is involved in the immune process directly or as a source of original VA merely. Therefore, this preliminary trial was conducted to study the effect of supplemental $\beta$-carotene in the periparturient diet at different levels on plasma VA and $\beta$-carotene concentrations and lymphocyte proliferation in Holstein cows.

\section{MATERIAL AND METHODS}

The trial was conducted in the Western Suburb Dairy Farm of Sanyuan Dairy Industry Group. Thirty six Holstein cows were selected according to their identical parity (second parity), last lactation milk yield (about $8.800 \mathrm{~kg} / \mathrm{year}$ ), body weight (625-650 kg), body condition score (BCS; 3.25-3.75) and expected calving date. The cows were randomly divided into three groups and individually fed with one of three treatment diets: 1 . control diet (basic diet $+150,000 \mathrm{IU}$ $\mathrm{VA} /$ cow/day), 2. control diet $+300 \mathrm{mg} \beta$-carotene/cow/day, and 3. control diet $+600 \mathrm{mg} \beta$-carotene/cow/day (Table 1). The trial lasted for 16 weeks, from 6 weeks before parturition (42 days before) to 12 weeks after parturition, with 2 weeks for adaptation.

Table 1. Ingredients and nutrient content of mixed concentrate

\begin{tabular}{lcc}
\hline Items & Prepartum & Postpartum \\
\hline Ingredient, \% in DM & & \\
maize grains & 50 & 47 \\
wheat bran & 14.5 & 11 \\
soyabean meal & 10 & 12 \\
cottonseed meal & 8 & 9 \\
rapeseed meal & 8 & 8 \\
linseed meal & 8 & 8 \\
1\% premix ${ }^{1}$ & & 1 \\
salt & 0.5 & 0.5 \\
limestone & 0 & 2 \\
sodium bicarbonate & 0 & 1.5 \\
Nutrient composition, \% in DM & & \\
CP & 22.8 & 23.2 \\
EE & 3.1 & 3.5 \\
NDF & 20 & 18.1 \\
ADF & 9.1 & 8.7 \\
Ca & 0.77 & 1.17 \\
P & 0.57 & 0.63 \\
NEI, MJ/kg in DM & 7.87 & 7.91 \\
\hline
\end{tabular}

${ }^{1}$ non-vitamin $\mathrm{A}$ in $1 \%$ premix 
All of the cows were fed equal quantity TMR. Each of the dry cows was fed 5 $\mathrm{kg}$ of prepartum concentrate diet, $4 \mathrm{~kg}$ of Chinese wild rye-grass hay, and $12 \mathrm{~kg}$ of whole maize plant silage per day. During the first week after calving, the cows were fed 6 to $11 \mathrm{~kg}$ of postpartum concentrate, $4 \mathrm{~kg}$ of Chinese wild rye-grass hay, and $16 \mathrm{~kg}$ of maize silage per day. During week 2-12 after calving the cows were fed $15 \mathrm{~kg}$ of a postpartum concentrate diet, $5 \mathrm{~kg}$ of Chinese wild rye-grass hay, and $20 \mathrm{~kg}$ of maize silage per day.

Blood was sampled from jugular vein before morning feeding on week - 4 (immediately prior to $\beta$-carotene supplementation), $-1,0$ (within $36 \mathrm{~h}$ post calving), 1 , and 4 for isolation of plasma and lymphocytes. The anticoagulant EDTA and heparin were used for isolating lymphocytes and plasma, respectively. $\beta$-carotene, VA concentration were analysed by HPLC based on the procedure of Arnaud et al. (1991). The method of Tjoelker et al. (1988) was followed for determination of the rate of blood lymphocyte proliferation stimulated by concanavalin A (Con A).

All data were analysed by the General Linear Model procedure of SAS (1996), using a completely randomized split-plot ANOVA. The final statistical model used was:

$$
\mathrm{Y}_{\mathrm{ij}}=\mu+\mathrm{T}_{\mathrm{i}}+\mathrm{W}_{\mathrm{j}}+\mathrm{TW}_{\mathrm{ij}}+\mathrm{E}_{\mathrm{ij}}
$$

where: $Y_{i j}$ - measured values in animal trial; $\mu$ - overall mean response; $T_{i}$ - effect of the treatment; $\mathrm{W}_{\mathrm{j}}$ - effect of the week relative to calving; $\mathrm{TW}_{\mathrm{ij}}$ - interaction of the treatment by week; $\mathrm{E}_{\mathrm{ij}}$ - error term.

\section{RESULTS}

As shown in Table 2, plasma $\beta$-carotene concentrations increased sharply around calving ( -4 to $4 \mathrm{wk} ; \mathrm{P}<0.05$ ) along with increasing $\beta$-carotene supplementation in the diet. Plasma $\beta$-carotene concentrations were higher for $\beta$-carotene supplemented animals than for control animals $(\mathrm{P}<0.05)$, except at calving time $(\mathrm{P}=0.125)$. Plasma $\beta$-carotene concentrations in all animals were declined to the lowest level at calving time, and then gradually increased to higher levels after calving.

Table 2. Effects of $\beta$-carotene supplementation on plasma $\beta$-carotene concentration of dairy cows in the periparturient period

\begin{tabular}{|c|c|c|c|c|c|}
\hline \multirow{2}{*}{$\begin{array}{l}\text { Plasma } \beta \text {-carotene } \\
\text { concentration, } \mu \mathrm{g} / \mathrm{ml}\end{array}$} & \multicolumn{3}{|c|}{$\beta$-carotene supplemental level, $\mathrm{mg} / \mathrm{head} /$ day } & \multirow{2}{*}{ SEM $^{1}$} & \multirow{2}{*}{$\mathrm{P}$} \\
\hline & 0 & 300 & 600 & & \\
\hline \multicolumn{6}{|l|}{ Prepartum } \\
\hline 4 wks & $1.0838^{\mathrm{b}}$ & $2.3285^{\mathrm{a}}$ & $2.6360^{\mathrm{a}}$ & 0.34 & 0.022 \\
\hline $1 \mathrm{wk}$ & $1.0280^{\mathrm{b}}$ & $1.3423^{\mathrm{b}}$ & $2.8703^{\mathrm{a}}$ & 0.42 & 0.027 \\
\hline Calving & 0.7758 & 0.6883 & 1.2378 & 0.32 & 0.125 \\
\hline \multicolumn{6}{|l|}{ Postpartum } \\
\hline $1 \mathrm{wk}$ & $0.8980^{\mathrm{b}}$ & $1.2938^{\mathrm{b}}$ & $2.3245^{\mathrm{a}}$ & 0.29 & 0.019 \\
\hline 4 wks & $0.8972^{b}$ & $1.6743^{\mathrm{a}}$ & $1.8588^{\mathrm{a}}$ & 0.21 & 0.020 \\
\hline
\end{tabular}

${ }^{1}$ SEM - standard error of means

${ }^{a}$ means without common superscripts in the same line differ significantly $(\mathrm{P}<0.05)$ 
Table 3 showed that plasma VA concentrations for all treatment animals followed a similar tendency with plasma $\beta$-carotene concentrations. At all time points except for 4 wk prepartum and 4 wk postpartum, plasma VA concentrations were not significantly $(\mathrm{P}>0.1)$ different among three $\beta$-carotene supplementation levels, although $\beta$-carotene supplementation treatments had numerically higher VA concentrations than control.

Table 3. Effects of $\beta$-carotene supplementation on plasma VA concentration of dairy cows in the periparturient period

\begin{tabular}{|c|c|c|c|c|c|}
\hline \multirow{2}{*}{$\begin{array}{l}\text { Plasma VA } \\
\text { concentration, IU/ml }\end{array}$} & \multicolumn{3}{|c|}{$\beta$-carotene supplemental level, $\mathrm{mg} / \mathrm{head} /$ day } & \multirow{2}{*}{ SEM $^{1}$} & \multirow{2}{*}{$\mathrm{P}$} \\
\hline & 0 & 300 & 600 & & \\
\hline \multicolumn{6}{|l|}{ Prepartum } \\
\hline 4 wks & $0.1163^{\mathrm{b}}$ & $0.2225^{\mathrm{ab}}$ & $0.1643^{\mathrm{a}}$ & 0.03 & 0.044 \\
\hline $1 \mathrm{wk}$ & 0.1995 & 0.2418 & 0.3143 & 0.09 & 0.691 \\
\hline \multicolumn{6}{|l|}{ Postpartum } \\
\hline $1 \mathrm{wk}$ & 0.1293 & 0.1320 & 0.1475 & 0.91 & 0.913 \\
\hline 4 wks & $0.0770^{\mathrm{b}}$ & $0.2173^{\mathrm{a}}$ & $0.2133^{\mathrm{a}}$ & 0.01 & 0.001 \\
\hline
\end{tabular}

${ }^{1}$ SEM - standard error of means

${ }^{a}$ means without common superscripts in the same line differ significantly $(\mathrm{P}<0.05)$

Table 4 showed the rate of lymphocyte proliferation as affected by $\beta$-carotene supplemental treatments at 5 time points during periparturient period. Lymphocyte proliferation indexes at $1 \mathrm{wk}$ prepartum, 1 and $4 \mathrm{wks}$ postpartum were significantly different $(\mathrm{P}<0.05)$ among $\beta$-carotene supplemental treatments. The lymphocyte proliferation index for all cows decreased to a low level in the calving week, but there was no difference among the $\beta$-carotene supplemental levels $(\mathrm{P}=0.71)$. The lymphocyte proliferation indexes for 300 and $600 \mathrm{mg}$ of $\beta$-carotene supplemental levels were quickly restored to relatively high levels after $1 \mathrm{wk}$ postpartum, but only slowly achieved to a stable level for control animals.

Table 4. Effect of $\beta$-carotene on blood lymphocyte proliferation in response to Con $\mathrm{A}^{1}$

\begin{tabular}{|c|c|c|c|c|c|}
\hline \multirow{2}{*}{$\begin{array}{l}\text { Lymphocyte proliferation } \\
\text { index }\end{array}$} & \multicolumn{3}{|c|}{$\beta$-carotene supplemental level, $\mathrm{mg} / \mathrm{head} / \mathrm{day}$} & \multirow{2}{*}{$\mathrm{SEM}^{2}$} & \multirow{2}{*}{$\mathrm{P}$} \\
\hline & 0 & 300 & 600 & & \\
\hline \multicolumn{6}{|l|}{ Prepartum } \\
\hline 4 wk & 1.17 & 1.19 & 1.18 & 0.03 & 0.883 \\
\hline $1 \mathrm{wk}$ & $1.25^{\mathrm{c}}$ & $1.66^{\mathrm{b}}$ & $1.42^{\mathrm{a}}$ & 0.04 & 0.001 \\
\hline Calving & 1.24 & 1.28 & 1.25 & 0.03 & 0.710 \\
\hline \multicolumn{6}{|l|}{ Postpartum } \\
\hline $1 \mathrm{wk}$ & $1.17^{\mathrm{b}}$ & $1.26^{\mathrm{ab}}$ & $1.53^{\mathrm{a}}$ & 0.09 & 0.045 \\
\hline $4 \mathrm{wk}$ & $1.33^{\mathrm{c}}$ & $1.45^{\mathrm{a}}$ & $1.40^{\mathrm{b}}$ & 0.01 & 0.001 \\
\hline
\end{tabular}

${ }^{1}$ Con A: concanavalin A, a lectin derived from the jack bean

${ }^{2}$ SEM - standard error of means

${ }^{\text {a }}$ means without common superscripts in the same line differ significantly $(\mathrm{P}<0.05)$ 


\section{DISCUSSION}

The present results showed that either plasma $\beta$-carotene or VA concentration had a dose-dependent response to the dietary $\beta$-carotene supplementation. Many researches have reported the similar conclusion that $\beta$-carotene and VA concentration in plasma increased with the supplementation of $\beta$-carotene in the diet (Akordor et al., 1986; Tjoelker et al., 1990). However, Oldham et al. (1991) showed that addition of $300 \mathrm{mg} \beta$-carotenes had no effect on plasma VA concentration, while supplementation of $50,000 \mathrm{IU}$ of VA with $300 \mathrm{mg} \beta$-carotene in the diet would increase plasma $\beta$-carotene concentration in periparturient period.

Some research results showed that $\beta$-carotene could promote lymphocytes proliferation. The process of lymphocyte proliferation was enhanced by supplied $\beta$-carotene 300 and $600 \mathrm{mg} / \mathrm{d}$ in periparturient diet, while supplementation of VA had no such effect (Heirman et al., 1990; Michal et al., 1994). These results further demonstrated that $\beta$-carotene plays a special role which is different from VA. However, the opposite conclusion showed that in the condition of adequate $\mathrm{VA}$ in the diet, $\beta$-carotenes increased serum $\beta$-carotene concentration of dry cows, but there were no significant differences in the function of neutrophils and lymphocytes in blood (Tjoelker et al., 1990). The researcher proposed that the content of $\beta$-carotenes in the diet was likely enough for the roles that neutrophils and lymphocytes would play.

\section{CONCLUSIONS}

$\beta$-carotene and vitamin A concentration in plasma increased along with increasing the $\beta$-carotene supplementation in the diet of dairy cows. $\beta$-carotene increased the blood lymphocyte proliferation in response to concanavalin $\mathrm{A}$, and the proliferation was increased with adequate VA in the diet during periparturient period of dairy cows.

\section{REFERENCES}

Akordor F.Y., Stone J.B., Walton J.S., Leslie K.E., Buchanan-Smith J.G., 1986. Reproductive performance of lactating Holstein cows fed supplemental $\beta$-carotene. J. Dairy Sci. 69, 2173-2178

Arnaud J., Fortis I., Blachier S., Kia D., Favier A., 1991. Simultaneous determination of retinol, alphatocopherol and beta-carotene in serum by isocratic high-performance liquid chromatography. J. Chromatogr. 572, 103-116

Boon T., 1993. Teaching the immune system to fighter cancer. J. Sci. Amer. Mag. 268 (3), 30

Heirman L.R., Chew B.P., Wong T.S., Michal J.J., Standaert F.E., 1990. Effects of $\beta$-carotene on lymphocyte function in peripartum dairy cows. J. Dairy Sci. 73, Suppl., 166 (Abstr.) 
Michal J.J., Heirman L.R., Wong T.S., Chew B.P., Frigg M., Volker L., 1994. Modulatory effects of dietary $\beta$-carotene on blood and mammary leukocyte function in periparturient dairy cows. J. Dairy Sci. 77, 1408-1421

Oldham E.R., Eberhart R.J., Muller L.D., 1991. Effects of supplemental vitamin A or $\beta$-carotene during the dry period and early lactation on udder health. J. Dairy Sci. 74, 3755-3781

SAS, 1996. SAS System for Windows, Release 6.12, SAS Institute Inc. Cary, NC

Tjoelker L.W., Chew B.P., Tanaka T.S., Daniel L.R., 1988. Bovine vitamin A and $\beta$-carotene intake and lactational status. 2. Responsiveness of mitogen stimulated peripheral blood lymphocytes to vitamin A and $\beta$-carotene challenge in vitro. J. Dairy Sci. 71, 3120-3127

Tjoelker L.W., Chew B.P., Tanaka T.S., Daniel L.R., 1990. Effect of dietary vitamin A and $\beta$-carotene on polymorphonuclear leukocyte and lymphocyte function in dairy cows during the early dry period. J. Dairy Sci. 73, 1017-1022 